\title{
Integrating Building Information Modelling (BIM) and Sustainability to Greening Existing Building: Potentials in Malaysian Construction Industry
}

\author{
Nur Syamimi Zulkefli ${ }^{1}$, Faizul Azli Mohd-Rahim ${ }^{1 *}$, Nurshuhada Zainon ${ }^{1}$ \\ ${ }^{1}$ Center for Building, Construction \& Tropical Architecture (BuCTA), Faculty of Built Environment, \\ University of Malaya, 50603 Kuala Lumpur, MALAYSIA \\ *Corresponding Author
}

DOI: https://doi.org/10.30880/ijscet.2020.11.03.008

Received 05 November 2019; Accepted 27 March 2020; Available online 30 June 2020

\begin{abstract}
Apropos to numerous environmental issues highlighted globally and locally, Malaysia has now moving forward towards new agenda of greening the cities. A positive movement trend of new green building in the country can be seen as number of projects going into green rating application are increasing yearly. Nevertheless, sustainability impact is considered as significantly small since newly developed green building represent small percentage as compared to the existing non-green building. Therefore, the idea of greening the existing building through refurbishment emerged in order to achieve wider sustainability objectives. Apart from that, supported with recent evolvement of technology and digitalization in construction industry, in lieu with governments' strategies to adopt Industry 4.0, Building Information Modelling (BIM) has also been acknowledged and used broadly as a solution to integrate and facilitate management of information throughout building lifecycles. Considering these two areas; sustainability and BIM are continuously gaining momentum these days, this paper attempts to explore BIM's potentials as an enabler to help greening the existing non-green building. Literature review is conducted focus on reviewing BIM and sustainability present status in Malaysian construction industry, also their relationship including examining potential areas where BIM may contribute to enhance the buildings' sustainability performances. Based on the reviews, there is a potential of bridging the two areas considering both has becoming a national construction industry agenda since the government released CITP2016-2020. To further concur the ideas, literature reviews has also proven that the ability of BIM to facilitate various functions has enable it to support several sustainability analyses such as energy, carbon emission, lighting, water, materials and waste, building and site, and costing analysis.
\end{abstract}

Keywords: Building Information Modelling, green BIM, sustainability, greening existing building

\section{Introduction}

Recently, existing building stock available which has been constantly releasing energies throughout its operation stage has been revealed to significantly affecting current environmental phenomenon (Ankrah \& Ahadzie, 2014). Leung (2018) indicates that almost $30 \%$ of total energy use globally nowadays comes from use phase of existing non-green building. Consequently, despite various sustainable efforts conducted these days, the impacts is still considered as small (Brooke, 2011; Nazri et al., 2013) considering percentage of existing building stock is higher than numbers of newly developed green building (Zhang, Wu, \& Liu, 2018; Zhou et al., 2016). Corresponding from the issues, researchers has 
started to embark on the concept of 'greening existing building'. 'Going green' has become a very often used terms when it comes to the idea of incorporating sustainability aspects. The term 'green' in a way has been used interchangeably with 'sustainable' in numerous literature.

The concept corroborates with the idea suggested by Zhou et al. (2016) and Vilches, Garcia-Martinez, and SanchezMontañes (2017). The researchers highlight the needs of refurbishing existing non-green building by incorporating various sustainability strategies to reduce existing environmental impacts. On the other hand, to further support the concept, UN Environment and International Energy Agency (2017) through its Global Alliance for Buildings and Constructions (GABC) key priorities roadmap has targeted to increase numbers of buildings refurbishment with regards to improve its performance and energy efficiency.

Recognizing the issue, construction industry players has recently notice the ability to adopt BIM concept towards achieving better sustainability values of the building (Jalaei \& Jrade, 2015). Of late, BIM has been acknowledged as a keystone for construction digitalization (Santos, Costa, Silvestre, \& Pyl, 2019). Considering BIMs' ability to facilitate multi-disciplinary information and transforming it into a model, Jalaei and Jrade (2015) highlight the opportunity of incorporating sustainability components into BIM system. Integration of these two principles allow BIM to be used as a support system at initial decision making stage. Among BIM possibilities mentioned by Jalaei and Jrade (2015) include experimental structural analysis, environmental controls, construction method, selecting new materials and systems, and detailed analysis of the whole processes. The integration has somehow lead to the emergence of 'Green BIM' terms. As define by Ismail et al. (2019), 'Green BIM' refers as integrating the sustainable practice which related to preserving impacts towards the environmental and surroundings using the application of BIM tools.

Despite outgrowing numbers of research and publication related to green BIM globally, this study concern on what is happening in the local construction industry, particularly in relation to BIM and sustainability (or green) integration. In response to the previously addressed question, the purposes of this study are twofold: (i) to review existing adoption of BIM and sustainability in Malaysian construction industry including looking into policies and initiatives by related parties, and (ii) to explore the potentials of integrating the two areas (BIM and sustainability) towards improving the existing building performances.

\section{Literature Review}

\subsection{BIM Evolvement in Malaysia}

Malaysian construction industry although indicated as one crucial sector contributing to country's growth, was reported to be among the industries with low levels of productivity and effectiveness (CIDB, 2017; Malaysia Productivity Corporation, 2016). Accordingly, to overcome the issues, as well as embracing new revolution, BIM was introduced. As denotable example of ICT (Hosseini et al., 2017), BIM perceived numerous benefits which is believed to be able to steer the industry towards achieving better performances, enhancing efficiency, productivity, and quality (CIDB, 2017). Realising the pros of ICT and BIM to the construction industry, in lieu with global practices, Malaysian construction industry has started to embark into the journey.

Reminiscing the past, the Malaysian private sectors has started to explore BIM since the early 2000 (Zainon, MohdRahim, Aziz, Kamaruzzaman, \& Puidin, 2018). However, it was officially introduced by Public Work Department (PWD) later in 2007 (Latiffi, Mohd, \& Brahim, 2015). During the time, the implementation was limited to its internal projects only (Ismail, Chiozzi, \& Drogemuller, 2017). Following the steps, a specific team has been set up by CIDB in 2008 to help creating awareness and promoting ICT and BIM amongst industry players (Haron et al., 2015; Ismail et al., 2017). The first BIM national conference was conducted later in 2009 (Haron et al., 2015) where the Director of PWD (Datuk Seri Prof Judin Abdul Karim) insisted the industry players towards adopting ICT to efficiently manage their projects to achieve better productivity. Similarly, the director emphasized on the importance of using integrated software system (i.e. BIM) to standardize the workflow throughout project planning and implementation (Haron et al., 2015; Sani, 2009). Subsequently, the government of Malaysia launched its first BIM-adopted project in 2010 called the National Cancer Institute (NCI) in Putrajaya, Malaysia (Haron et al., 2015; Ismail et al., 2017; Latiffi et al., 2015; Musa, Marshall-Ponting, Abdul Nifa, \& Shahron, 2018).

In 2011, CIDB received the mandate from the government to lead the BIM implementation in Malaysia (Ismail et al., 2017). Ever since, they have been proactively initiating, promoting and supporting BIM adoption in Malaysian construction industry. Among significant efforts made was involving the policy makers, practitioners, and academicians in forming a steering committee for BIM, BIM Roadmap, and BIM Portal (CIDB, 2016; Zainon et al., 2018). Other determinations include organizing numerous awareness programs, seminars, and workshop to facilitate and communicate with industry players pertaining to BIM implementation (CIDB, 2017). It has been noted that till date, more than 20 projects has been utilizing BIM concept as a tool to manage their projects at varies maturity level (Musa et al., 2018).

BIM evolvement in Malaysia was clearly nurtured by the involvement of both public and private sectors. The government of Malaysia has recently plays their role objectively by endorsing more policies and regulations pertaining to BIM adoption. Previously, government jointly with CIDB has develop the Construction Industry Transformation Programme (CITP) 2016-2020 primarily focusing on transforming the industry to become more productive, sustainable and competitive (CIDB, 2015). Among the strategic thrusts available include highlighting on efforts and strategies to 
raise the local construction industry's productivity level through adoption of ICT such as BIM. CITP aims that by 2020, BIM implementation will reach Stage 2 maturity and has been implemented at a minimum rate of $40 \%$ among projects valued at RM 100million and above (CIDB, 2015, 2017).

Apart from that, recent national agenda on IR 4.0 has eventually helps stimulate BIM adoption towards achieving digitalized construction industry too. Moving forward with manufacturing industry, the term 'Construction 4.0' was coined as a branch of IR 4.0 that focus specifically on digitalizing the AEC industry (Razali \& Sullivan, 2018). Malaysian construction industry through CIDB is currently working on its own IR 4.0 roadmap aims at providing improved and clearer direction to the construction industry players. It aims to especially focus on endorsing BIM (Ahmad, 2018) as major tool to be used in the industry. The roadmap is expected to be release by January 2020 covering five years' period until 2025.

In summary, it is best to note that BIM implementation in Malaysia is progressing positively. A report produced by CIDB recently has recorded that during the survey, the adoption rate of BIM in Malaysia was 16\% (CIDB, 2017). Though the percentage was considered as low if compared against developed countries like United States (71\%) and United Kingdom (54\%) (Lin Star Property, 2018), with vast efforts and supports from all relevant parties on BIM adoption, it is predicted that the technology will continue to be used widely among Malaysian construction projects in the near future.

\subsection{Sustainable Development in Malaysia}

In contrast to BIM, sustainability has becoming the talk of the town in Malaysia long way before. Initiated by the government efforts ratifying the Kyoto Protocol in 2004, Malaysia's priority at the time was on upgrading the citizen's standard of livings and eliminating of poverty (Lian, 2018). However, due to growth of population and migration of people to urban areas, demand for housing and facilities has been increasing (Rostami, Khoshnava, Rostami, \& Lamit, 2015). With vast developments happening during the years, several issues have been highlighted including excessive resource consumption, pollution, and waste generation. This has becoming a push factor to construction industry in preserving the environmental towards accommodating the rising demand. To accommodate the issues, in support with Kyoto Protocol, Construction Industry Master Plan (CIMP) 2006-2015 was released in 2006 (CIDB, 2006). Major aims of CIMP include emphasizing environmental sustainability towards attaining and satisfying national growth of economic and social development (CIDB, 2006; Rostami et al., 2015).

National Green Technology Policy (NGTP) was then released in 2009 promoting sustainable development by focusing on minimizing the energy consumption growth through low carbon technology and conservation of nature and natural resources (Chua \& Oh, 2011; Masrom, Abd Rahim, Ann, Mohamed, \& Goh, 2017; National Property Information Center, 2012). Since then, various policies, incentives and measures has been introduced by both public and private sectors to inculcate sustainable development in construction industry. This includes growing of numerous newly developed green building rating tools (GBRT) to support building performance assessment towards achieving green certification. To ensure continuous efforts, sustainability was again being accentuated in Eleventh Malaysia Plan (RMK11) and CITP 2016-2020. A specific thrust was highlighted emphasizing on incorporating environmental sustainability in overall process of design, during construction and subsequent building and infrastructure phases including maintenance and operation (CIDB, 2015).

The government of Malaysia later in 2016 has voluntarily commit to decrease its overall GHG emission up to $40 \%$ in relation to country's 2005 GDP by the year 2030 (Lian, 2018). The pledge was made with regards to the government's decision to ratified Paris Agreement (PA) in 2016 as well as to achieve Sustainable Development Goals (SDG) established by the United Nations General Assembly (UNGA) in 2015. To achieve the target, Green Technology Master Plan (GTMP) Malaysia was developed and launched recently covering various efforts to be undertaken in between 2017 to 2030. GTMP serves as the national strategic framework to support the implementation of green strategies towards achieving sustainable objectives and high income country in 2020, as well as putting Malaysia as Green Technology center by 2030 (KeTTHA, 2017). GTMP highlights five major strategic thrusts including (1) promotion and awareness, (2) market enablers, (3) human capital development, (4) research development and commercialization, and (5) institutional framework. The thrusts will cover five major sectors in Malaysia such as manufacturing, transport, building, waste, water, and energy.

Specifically, in building sector, among the way forward targeted by GTMP includes emission reduction of both private and government building, increasing numbers of green certified buildings, improvement in sustainable construction practices and green building materials, and many more (KeTTHA, 2017). With recent launching of GTMP particularly, numerous green activities and efforts is expected to be put on by the industry players in coming years. Therefore, in lieu with BIM, sustainable development is expected to continuously grows in Malaysian construction industry too.

\subsection{The Nexus Between BIM and Sustainability in Malaysian Construction Industry}

Figure 1 outlines overall evolvement of BIM and Sustainability in Malaysia. From the past few years, these two areas have been progressing positively and becoming among the national agenda focused to improve overall construction industry growth and development. Both BIM (under productivity thrust) and Sustainability were mentioned as a specific 
strategic thrust in CITP2016-2020 (CIDB, 2015) (as shown in Figure 2). Continuously, numerous efforts and strategies has been put on by various public and private agencies to support the agenda towards aligning Malaysia into a developed nation.

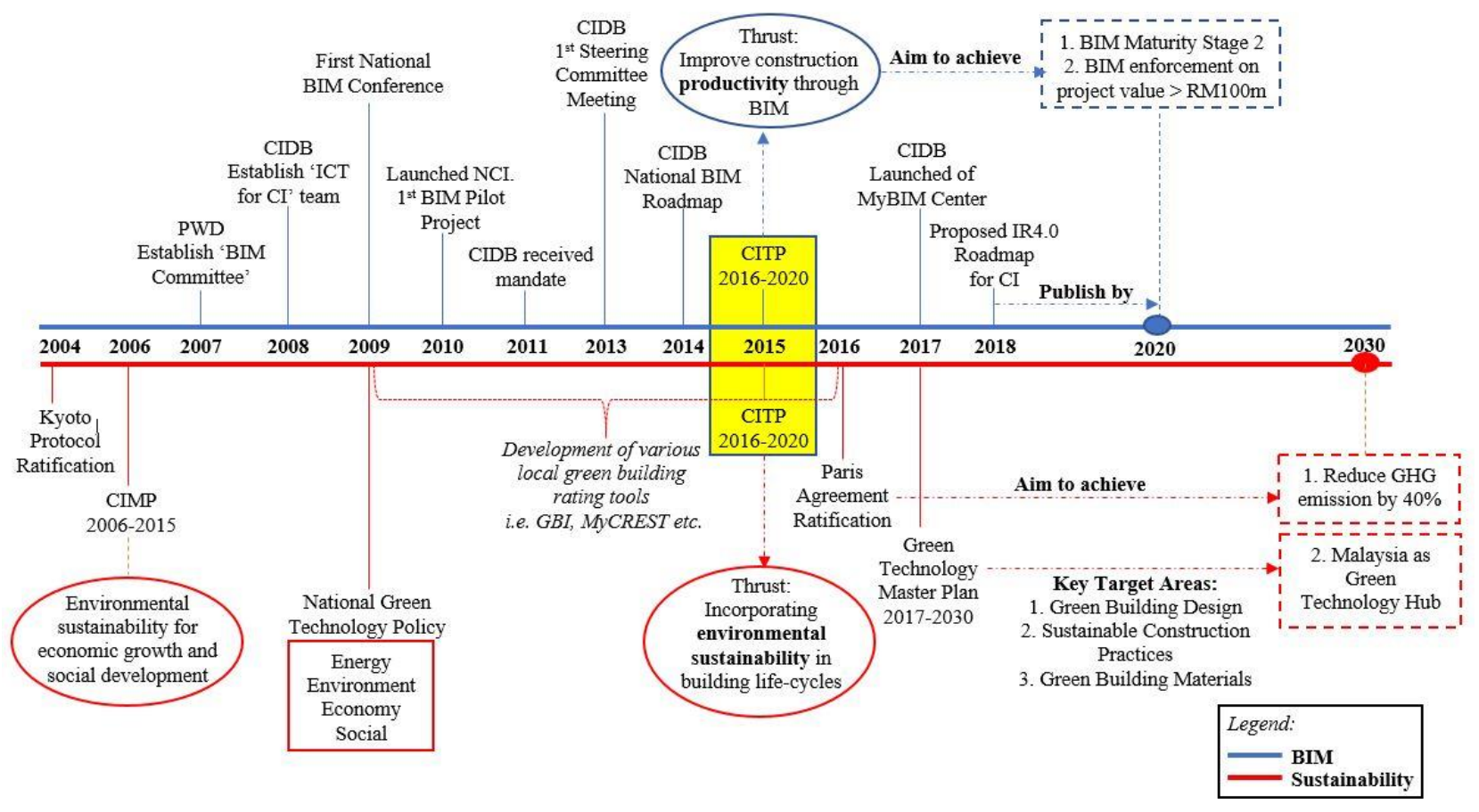

Fig. 1 - BIM and Sustainability evolvement timeline and target in Malaysian construction industry (developed by authors)

Additionally, it is expected for major refurbishment of existing building works among public or government buildings will be conducted within the years. This is due to government's target as highlighted in the Eleventh Malaysian Plan (2016-2020) to refurbished 100 government buildings in effort to improve its environmental performance and energy efficiency. The target eventually provides an opportunity for the building owners to upgrade the building as sustainable rated building. With growing attention on both areas, supported with various initiatives by relevant parties, it is foreseen that there is a potential of connecting the two (i.e. BIM and sustainability) towards achieving better performances of existing building.

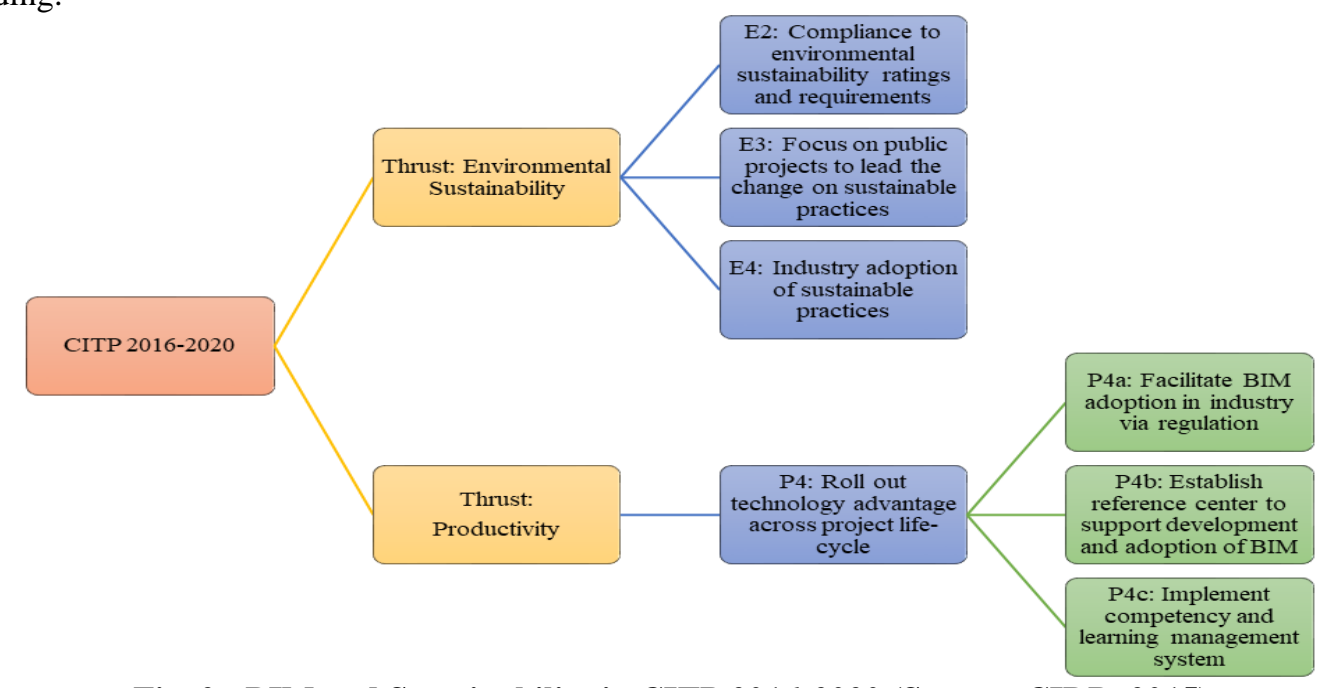

Fig. 2 - BIM and Sustainability in CITP 2016-2020 (Source: CIDB, 2015) 


\section{BIM for Greening Existing Building}

BIM has been significantly proven to be impactful and providing benefits (Eadie, Browne, Odeyinka, McKeown, \& McNiff, 2013) towards various stages in construction project lifecycle. Previous literature review has defined numerous function of BIM in every stages including feasibility study, pre-construction phase (design and tendering), construction, and operation and maintenance. Apart from that, Abanda, Vidalakis, Oti, and Tah (2015) had also list and critically review various BIM software systems available for every stages of construction including their functions and specific applications.

Consequently, with rapid development of research on BIM implementation throughout overall project life-cycle, there has been growing interest on applicability of BIM towards the later stages of project particularly on operational (use) stage. Volk, Stengel, and Schultmann (2014) mention that lately, research attention is shifting from earlier life cycle stages to potential of using BIM during post-occupancy period including building maintenance, refurbishment, deconstruction and end-of-life (Eastman, Eastman, Teicholz, \& Sacks, 2011; Joblot, Paviot, Deneux, \& Lamouri, 2017; McArthur, 2015; Volk et al., 2014). Previous research (Gholami, Kiviniemi, Kocaturk, \& Sharples, 2015; Habibi, 2017; Ilter \& Ergen, 2015; Khaddaj \& Srour, 2016; Scherer \& Katranuschkov, 2018) has also reveal that there is a strong relation on the potential of BIM to improve existing building performances including its quality and functionality (Scherer \& Katranuschkov, 2018) towards achieving energy efficiency building within optimal cost involvement. This has led to opportunity for integration of BIM as an innovative tool to achieve sustainability objectives of building through improvement on existing structure (Habibi, 2017).

\section{Potential Areas of Integration Between BIM and Sustainability}

Academically, substantial amount of research has been done globally on BIM potentials to support sustainable and green building development for the past few years. For instance, Wong and Zhou (2015) review numerous literature related to green BIM and building life cycles. $\mathrm{Lu}, \mathrm{Wu}$, Chang, and $\mathrm{Li}$ (2017) however mention that previous work by Wong and Zhou (2015) fail to highlight on various BIM applications for green building. To fill the gap, Lu et al. (2017) develop 'Green BIM Triangle' model to visualize BIM abilities to complement various sustainability principles throughout overall life cycle phases of building. Among the dimensions of the triangle includes 'green attributes' that highlight sustainability components which possible to be implemented through BIM tools such as energy, carbon emissions, solar and lighting, ventilation, material, and waste (Lu et al., 2017).

Previously, Kriegel and Nies (2008) recommended seven strategies to facilitate sustainability using BIM which include building orientation, building massing, daylighting optimization, water harvesting, energy modelling analysis, site and logistics management, and sustainable building materials. According to Kriegel and Nies (2008),

Building orientation involve analyzing how a structure is being positioned on the site pertaining to the sun's path throughout the year. Several data including site location's latitude, longitude, and solar path are required to finally decide on structure's orientation. BIM's tool is capable of positioning the structure's model into true location and orientation, thus allowing the project team to perform analysis and assessment on lighting, ventilation, heating and cooling. This can be achieved through visualization of structure during day or night, and during sunlight to foresee which area directly receive sun or experience shade.

Similarly, this ability supports building massing by comparing multiple massing configurations to calculate possible energy release and day lighting optimization. BIM enables the team to configure demand for artificial lighting which has been directly contribute towards internal heat gain and energy released. Apart from that, the fourth strategy related to water harvesting. By using a BIM model, roof components particularly can be analysed from the database thus eventually enables calculation of potential rainwater to be captured. The next approach is energy modeling and analysis. BIM allows energy analysis of specific components or materials to be done with relation to any appropriate energy analysis tools. Among the tools include Ecotect, Green Building Studio, eQUEST, EnergyPlus, and IES. It is very critical to identify the project requirements such as lighting, heating, cooling, and power needs. In some cases, the performance criteria may be depending on specific standards and codes such as LEED Green Building Rating Tools and others. BIM enables the design team to conduct the analysis, making alterations, repeat the same step-by-step process iteratively when comparing between different alternatives to achieve the performance criteria set.

The sixth strategy involve site and logistics management which refers to management of site to reduce carbon offset. Finally, the last strategy highlight on the use of sustainable building materials. Among critical evaluation include defining specific criteria for the materials to be considered as sustainable. This usually involved materials which are non-toxic, and able to minimize the amount of embodied energy released throughout its life cycle.

Differs to Kriegel and Nies (2008), Hardin (2009) outlines only three main areas of sustainable that can be directly linked to BIM including material selection and use, site selection and management, and system analysis. Azhar, Brown, and Farooqui (2009) on the other hand emphasize BIM and sustainability analysis especially on daylighting and solar access. Among other capabilities highlighted include material takeoffs, cost estimation, and construction schedules. Meanwhile, Hammond, Nawari, and Walters (2014) previously study on how BIM tools may be able to assist renovation of existing building towards achieving sustainability. The researchers emphasized two main categories of sustainability principles that can be integrated into BIM namely (1) building form, and (2) building function. 'Building form' principles 
consist of evaluating building orientation, massing, envelope and daylighting meanwhile 'building function' include energy, water, ventilation and lighting.

Soltani (2016) on the other hand categorized BIM contribution towards achieving sustainability based on its triple dimensions namely economic, environmental, and social. For each dimensions, Soltani (2016) identify various sustainability factors that can be implemented using BIM functions as well as suitable tools to be adopted. Example of sustainability factors include site and land use, materials, energy, water, operating and maintenance cost, health and well-being etc. Apart from that, BIM has been acknowledged for its ability to determine and analyze energy consumption of existing building, particularly during energy audit phase (Khaddaj \& Srour, 2016) which therefore able to precisely predict buildings' energy performances, creating models, and comparing between alternatives available (Habibi, 2017). Ilter and Ergen (2015) also add that data acquire from the BIM model can be integrate with costing software to estimate cost involved to greening the building. This eventually enable stakeholders to forecast economic value of the building thus assist their decision-making process.

\section{Conclusion}

This study presents a review on BIM and sustainability potentials of integration to improve sustainability performances of existing building. BIM and sustainability have received growing attention in both academic and industry particularly in Malaysia due to various initiatives induced by the relevant parties. With the provision of specific thrust on BIM adoption and sustainability efforts in CITP 2016-2020, the two areas have become the national agenda and expected to continuously grows in Malaysian construction industry. Similarly, the findings from literature add to our understanding that BIM as an innovative tool has the opportunity to facilitate the idea of greening the existing buildings. It was discovered that BIM enables various sustainability analysis including energy analysis, carbon emission analysis, lighting analysis, water analysis, materials and waste analysis, building and site analysis, and costing analysis. The ability of BIM to facilitate various functions including materials and quantity takeoff, costing, visualization and creating models has indirectly enables it to support aforementioned sustainability analysis.

In general, this study could potentially contribute to the understanding of construction project stakeholders on how various sustainable approach can help to improve the performances of existing buildings using BIM. However, the findings are restricted to the limitation that it does not discuss on any potential considerations or issues for the implementation. Some major gaps that could be consider for future study include availability of BIM data for existing buildings, interoperability issues, and specific BIM tools to be applied for the analysis. Additionally, the findings of this study partly contribute to ongoing research that aims to develop a model to greening existing building using BIM as tool, based on life cycle sustainability assessment (LCSA) approach.

\section{Acknowledgement}

This study is funded by the Fundamental Research Grant Scheme, FRGS/1/2020/SSI02/UM/02/1), Life Cycle Sustainability Assessment (LCSA) for Greening Existing Buildings through Building Information Modelling (BIM).

\section{References}

Abanda, F. H., Vidalakis, C., Oti, A. H., \& Tah, J. H. M. (2015). A critical analysis of Building Information Modelling systems used in construction projects. Advances in Engineering Software, 90, 183-201. doi:https://doi.org/10.1016/j.advengsoft.2015.08.009

Ahmad, R. (2018, December 27th, 2018). CIDB to establish IR 4.0 roadmap for construction industry. Bernama. Retrieved from https:/www.nst.com.my/business/2018/12/444298/cidb-establish-ir-40-roadmap-construction-industry

Ankrah, N. A., \& Ahadzie, D. K. (2014). Key Challenges of Managing Building Adaptation and Rerofit Projects. Structural Survey, 32(5). doi:https://doi.org/10.1108/SS-10-2014-0035

Azhar, S., Brown, J., \& Farooqui, R. (2009). BIM-based Sustainability Analysis: An Evaluation of Building Performance Analysis Software

Brooke, C. (2011). Retrofitting existing buildings: The low cost, high volume solution to climate change. Sustainability Asia Pacific, 4, 10-15

Chua, S. C., \& Oh, T. H. (2011). Green progress and prospects in Malaysia. Renewable and Sustainable Energy Reviews, $15,2850-2861$

CIDB. (2006). Construction Industry Master Plan (CIMP) 2006-2015. Construction Industry Development Board (CIDB) Malaysia. Kuala Lumpur, Malaysia 
CIDB. (2015). Construction Industry Transformation Programme 2016-2020: Driving Construction Excellence Together. Malaysia: Construction Industry Development Board (CIDB) Malaysia

CIDB. (2016). The BIM Guide 1: Awareness. Construction Industry Development Board (CIDB). Kuala Lumpur, Malaysia

CIDB. (2017). Malaysia BIM Report 2016. Construction Industry Development Board (CIDB) Malaysia. Kuala Lumpur, Malaysia

Eadie, R., Browne, M., Odeyinka, H., McKeown, C., \& McNiff, S. (2013). BIM implementation throughout the UK construction project lifecycle: An analysis. Automation in Construction, 36, 145-151. doi:https://doi.org/10.1016/j.autcon.2013.09.001

Eastman, C. M., Eastman, C., Teicholz, P., \& Sacks, R. (2011). BIM Handbook: A Guide to Building Information Modelling for Owners, Managers, Designers, Engineers and Contractor Hoboken, NJ: Wiley

Gholami, E., Kiviniemi, A., Kocaturk, T., \& Sharples, S. (2015). EXPLOITING BIM IN ENERGY EFFICIENT DOMESTIC RETROFIT: EVALUATION OF BENEFITS AND BARRIERS

Habibi, S. (2017). The promise of BIM for improving building performance. Energy and Buildings, 153, 525-548. doi:https://doi.org/10.1016/j.enbuild.2017.08.009

Hammond, R., Nawari, N. O., \& Walters, B. (2014). BIM in Sustainable Design: Strategies for Retrofitting/Renovation. Paper presented at the International Conference on Computing in Civil and Building Engineering, Orlando, Florida, USA

Haron, A. T., Marshall-Ponting, A., Zakaria, Z., Mohd Nawi, M. N., Abd Hamid, Z., \& Mohamad Kamar, K. A. (2015). An industrial report on the Malaysian Building Information Modelling (BIM) Ttaskforce: Issues and recommendations. Malaysia Construction Research Journal, 17(2), 21-36

Hosseini, M. R., Banihashemi, S., Rameezdeen, R., Golizadeh, H., Arashpour, M., \& Ma, L. (2017). Sustainability by Information and Communication Technology: A paradigm shift for construction projects in Iran. Journal of Cleaner Production, 168, 1-13. doi:https://doi.org/10.1016/j.jclepro.2017.08.200

Ilter, D., \& Ergen, E. (2015). BIM for building refurbishment and maintenance: current status and research directions. Structural Survey, 33(3), 228-256. doi:10.1108/SS-02-2015-0008

Ismail, N. A. A., Chiozzi, M., \& Drogemuller, R. (2017). An overview of BIM uptake in Asian developing countries. AIP Conference Proceedings, 1903. doi:https://doi.org/10.1063/1.5011596

Ismail, N. A. A., Ramli, H., Dewiyana Ismail, E., Rooshdi, R., Sahamir, S., \& Hidayah Idris, N. (2019). A Review on Green BIM Potentials in Enhancing the Construction Industry Practice. $266,01023$. doi:10.1051/matecconf/201926601023

Jalaei, F., \& Jrade, A. (2015). Integrating building information modeling (BIM) and LEED system at the conceptual design stage of sustainable buildings. Sustainable Cities and Society, 18, 95-107. doi:https://doi.org/10.1016/j.scs.2015.06.007

Joblot, L., Paviot, T., Deneux, D., \& Lamouri, S. (2017). Literature review of Building Information Modeling (BIM) intended for the purpose of renovation projects (Vol. 50)

KeTTHA. (2017). Green Technology Master Plan Malaysia 2017-2030. Ministry of Energy, Green Technology and Water (KeTTHA). Putrajaya, Malaysia

Khaddaj, M., \& Srour, I. (2016). Using BIM to Retrofit Existing Buildings. Procedia Engineering, 145, 1526-1533. doi:https://doi.org/10.1016/j.proeng.2016.04.192

Kriegel, E., \& Nies, B. (2008). Green BIM. Indianapolis: Wiley Publishing

Latiffi, A. A., Mohd, S., \& Brahim, J. (2015). Apllication of Building Information Modelling (BIM) in the Malaysian construction industry: A story of the first governement project. Applied Mechanics and Materials, 773-774, 943-948

Leung, B. C.-M. (2018). Greening existing buildings [GEB] strategies. Energy Reports, 4, 159-206. doi:https://doi.org/10.1016/j.egyr.2018.01.003

Lian, K. F. (2018). The Implications of the Paris Climate Agreement for Malaysia. International Journal of Science Arts and Commerce, 3(2), 27-39 
Lu, Y., Wu, Z., Chang, R., \& Li, Y. (2017). Building Information Modeling (BIM) for green buildings: A critical review and future directions. Automation in Construction, 83, 134-148. doi:https://doi.org/10.1016/j.autcon.2017.08.024

Masrom, M. A. N., Abd Rahim, M. H. I., Ann, S. C., Mohamed, S., \& Goh, K. C. (2017). A preliminary exploration of the barriers of sustainable refurbishment for commercial building projects in Malaysia. Procedia Engineering, 180, 13631371. doi:https://doi.org/10.1016/j.proeng.2017.04.299

McArthur, J. J. (2015). A Building Information Management (BIM) Framework and Supporting Case Study for Existing Building Operations, Maintenance and Sustainability. Procedia Engineering, 118, 1104-1111. doi:https://doi.org/10.1016/j.proeng.2015.08.450

Musa, S., Marshall-Ponting, A., Abdul Nifa, F. A., \& Shahron, S. A. (2018). Building Information Modelling (BIM) in Malaysia construction industry: Benefits and future challenges. AIP Conference Proceedings, 2016. doi:https://doi.org/10.1063/1.5055507

National Property Information Center. (2012). Propert Stock Report: Commercial Property Stock Table Q4 2012. National Property Information Center. Malaysia.

Nazri, A. Q., Mohammad, I. S., Baba, M., Lokman, M. A. A., Woon, N. B., Ramli, N. A., \& Zainol, N. N. (2013). The need for retrofitting to achieve sustainability of Malaysian buildings. Jurnal Teknologi (UTM Press)

Razali, N. T. M., \& Sullivan, N. (2018). Making Sense of Malaysia's Fourth Industrial Revolution - Construction: Sustaining Growth Through Technology. Malaysian Foresight Institute. Malaysia. Retrieved from https://www.myforesight.my/2018/09/21/making-sense-of-malaysias-fourth-industrial-revolution-constructionsustaining-growth-through-technology/

Rostami, R., Khoshnava, S. M., Rostami, R., \& Lamit, H. (2015). Green and sustainability policy, practice and management in construction sector; A case study of Malaysia. Research Journal of Applied Sciences, Engineering and Technology, 9(3), 176-188.

Santos, R., Costa, A. A., Silvestre, J. D., \& Pyl, L. (2019). Integration of LCA and LCC analysis within a BIM-based environment. Automation in Construction, 103, 127-149. doi:https://doi.org/10.1016/j.autcon.2019.02.011

Scherer, R. J., \& Katranuschkov, P. (2018). BIMification: How to create and use BIM for retrofitting. Advanced Engineering Informatics, 38, 54-66. doi:https://doi.org/10.1016/j.aei.2018.05.007

Soltani, S. (2016). The Contributions of Building Information Modelling to Sustainable Construction. World Journal of Engineering and Technology 2016, 4, 193-199. doi:http://dx.doi.org/10.4236/wjet.2016.42018

UN Environment, \& International Energy Agency. (2017). Towards a zero-emission, efficient and resilient buildings and construction sector: Global Staturs Report 2017. Retrieved from

Vilches, A., Garcia-Martinez, A., \& Sanchez-Montañes, B. (2017). Life cycle assessment (LCA) of building refurbishment: A literature review. Energy and Buildings, 135, $286-301$. doi:https://doi.org/10.1016/j.enbuild.2016.11.042

Volk, R., Stengel, J., \& Schultmann, F. (2014). Building Information Modeling (BIM) for existing buildings — Literature review and future needs. Automation in Construction, 38, 109-127. doi:https://doi.org/10.1016/j.autcon.2013.10.023

Wong, J. K. W., \& Zhou, J. (2015). Enhancing environmental sustainability over building life cycles through green BIM: A review. Automation in Construction, 57, 156-165. doi:10.1016/j.autcon.2015.06.003

Zainon, N., Mohd-Rahim, F. A., Aziz, N. M., Kamaruzzaman, S. N., \& Puidin, S. (2018). Cathching up with Building Information Modeling: Challeneges and opportunities for Quantity Surveyors. Journal of Surveying, Construction and Property (JSCP), 9(1), 19-31

Zhang, L., Wu, J., \& Liu, H. (2018). Turning green into gold: A review on the economics of green buildings. Journal of Cleaner Production, 172, 2234-2245. doi:https://doi.org/10.1016/j.jclepro.2017.11.188

Zhou, Z., Zhang, S., Wang, C., Zuo, J., He, Q., \& Rameezdeen, R. (2016). Achieving energy efficient buildings via retrofitting of existing buildings: a case study. Journal of Cleaner Production, 112, 3605-3615. doi:https://doi.org/10.1016/j.jclepro.2015.09.046 